\title{
IMPROVING THE LANGUAGE SKILLS OF PUPILS IN KINDERGARTEN - AN EXAMPLE OF GOOD PRACTICE
}

\section{[ZLEPSOVANIE JAZYKOVYCH SCHOPNOSTI ZIAKOV V MATERSKEJ SKOLE - PRIKLAD DOBREJ PRAXE]}

\section{Viktor Gatial}

doi: 10.18355/PG.2020.9.2.7

\begin{abstract}
The author presents an example of good practice in the direction of systematic development of children's language skills in kindergarten. Language skills, and especially phonemic awareness, are the so-called strong predictors of possible problems, resp. written language disorders in the future. By deliberately developing them, it is possible to eliminate these problems, or reduce the risk of speech disorders. However, it is necessary to use appropriate methods, such as e.g. metacognitive strategies. One of them is the Phonemic Awareness Training according to D. B. Elkonin, which was also used in the presented research. Using this method, the language skills of a group of 21 preschool children in kindergarten were significantly improved. The results show a significant improvement in children's language skills.
\end{abstract}

\section{Key words}

Predictors of written speech disorders, language skills, phonemic awareness training according to D. B. El'konin, preschool age, kindergarten

\begin{abstract}
Abstrakt
Autor v článku predstavuje príklad dobrej praxe v smere systematického rozvíjania jazykových schopností detí v materskej škole. Jazykové schopnosti, a z nich najmä fonematické uvedomovanie, sú tzv. silnými prediktormi možných problémov, resp. porúch písanej reči v budúcnosti. Ich zámerným rozvíjaním je možné uvedené problémy eliminovat', prípadne zniźit' riziko vzniku porúch písanej reči. Je však potrebné pritom použit' primerané metódy, akými sú napr. metakognitívne stratégie. Jednou z nich je Tréning fonematického uvedomovania podla D. B. El'konina, ktorý bol použitý aj predkladanom výskume. Pomocou tejto metódy sa podarilo významne zlepšit' jazykové schopnosti skupiny 21 detí predškolskej triedy v materskej škole. Výsledky poukazujú na významné zlepšenie jazykových schopností detí.
\end{abstract}

\section{Kl’účové slová}

Prediktory porúch písanej reči, jazykové schopnosti, tréning fonematického uvedomovania podl'a D. B. El'konina, predškolský vek, materská škola

Úvod

Aktuálne je jazykovo-kognitívna teória vzniku problémov, prípadne porúch písanej reči, prezentovaná ako najmodernejší prístup k tejto 
problematike. Uvedená teória je založená na overenom predpoklade o podmienenosti porúch čítania a písanej reči najmä jazykovými schopnost’ami. Z toho vyplýva, že ich systematickým rozvojom je možné uvedené problémy eliminovat', prípadne znížit riziko vzniku porúch písanej reči, a s tým súvisiacich možných problémov v akademickom výkone žiakov, prípadne problémov osobnostných, či sociálnych. Ako uvádza Mikulajová: „Raná predikcia vývinových porúch písanej reči je principiálne možná skôr, ako sa prejavia prvé symptómy zlyhania diet’ata v učení. Tradičný koncept posudzovania pripravenosti diet'ata na školu, špecificky na čítanie a písanie, je načase nahradit' novým, ktorý sa opiera predovšetkým o jazykovokognitívne schopnosti“ (Mikulajova, M. 2008, p. 67). Je však potrebné pritom použit' primerané metódy, akými sú napr. metakognitívne stratégie. Jednou $\mathrm{z}$ nich je Tréning fonematického uvedomovania podla D. B. El'konina. V nasledovnom texte uvádzame prehl'ad tzv. silných prediktorov problémov $\mathrm{v}$ čítaní a písanej reči, krátky exkurz do princípov tréningu fonematického uvedomovania a výsledky aplikovaného výskumu úrovne jazykových schopností 21 detí predškolskej triedy materskej školy vplyvom vyššie uvedenej preventívnej metódy.

\section{Prediktory problémov písanej reči}

Pojmom „písaná reč“ sa v súčasnosti označuje súhrn čitatel'ských, pisatel'ských a pravopisných zručností. Moderné výskumy uvádzajú ich úzky súvis s jazykovými a kognitívnymi schopnostami. Do našej psychologickej, špeciálno-pedagogickej, prípadne pedagogickej praxe, sa však tieto poznatky premietajú len vel'mi pomaly - dôkazom je tradičný koncept identifikácie predškolákov, ktorí nezodpovedajú kritériám školskej pripravenosti, skúmaním ich fyzickej, kognitívnej, emocionálnej, sociálnej, rečovej a motorickej oblasti, a to použitím metód, ktoré vznikli pred niekol'kými desiatkami rokov (Mikulajova, 2008).

V rámci uvedených oblastí sa skúma vzrast a telesné proporcie, hrubá a jemná motorika a grafomotorika, zraková a sluchová percepcia a diferenciácia, krátkodobá a dlhodobá pamät', vizuomotorická koordinácia, pravo-l’avá orientácia, prípadne lateralita, všeobecné rozumové schopnosti. $\mathrm{K}$ ich zistovaniu máme $\mathrm{k}$ dispozícii celý rad štandardizovaných aj neštandardizovaných metód. V prípade intaktných predškolákov nás skúmanie týchto ukazovatel'ov presvedčí vo väčšine prípadov o ich školskej pripravenosti. Ak však ide o predškolákov, na ktorých $\mathrm{v}$ rámci ich vývinu pôsobia negatívne vnútorné, či vonkajšie vplyvy, môže sa stat', že ich danými metódami nezachytíme. Dôvodom je, že tieto metódy nemerajú v súčasnosti známe významnejšie prediktory, ktoré ovplyvňujú osvojovanie si trívia žiakmi. Takýmito prediktormi sú najmä jazykové a kognitívne funkcie. Ich kvalita zároveň predikuje ohrozenie špecifickými vývinovými poruchami učenia. V súvislosti s poruchami učenia (resp. písanej reči) sú aktuálne uvádzané ako ich bezprostredné príčiny oslabenia špecifických jazykovo kognitívnych schopností, ktoré sú na pozadí úspešného osvojenia si čítania. Hovoríme tak o tzv. prediktoroch čítania, ku ktorým zarad’ujeme fonologické uvedomovanie, rýchle automatické pomenovanie (RAN), pracovnú pamät', 
gramatický cit, naratívne schopnosti, porozumenie reči, poznanie písmen (Mikulajova, 2009, Hulme a Snowlingova, 2009).

Fonematické uvedomovanie je jazyková schopnost' považovaná za jeden z najvýznamnejších prediktorov porúch čítania. Mikulajova (2012) uvádza, že takmer 100\% dyslektikov vykazuje fonologický deficit nejakého druhu. Zároveň však dodáva, že fonologická hypotéza nie je vyčerpávajúca, pretože fonologické schopnosti nie sú jedinými prediktormi budúceho čítania (okrem nich ešte slovná zásoba a gramatické schopnosti), a že dyslexiou sú rovnako ohrození predškoláci s fonologickými ako aj nefonologickými jazykovými deficitmi (Scarboroughova, In Mikulajova a kol., 2012). Snowlingová (2000) obhajuje jednoznačne fonologické pozadie vzniku dyslexie. Autorka uvádza, že okrem fonologického deficitu (slabá schopnost' fonologických predstáv) má pri vzniku dyslexie vplyv aj obmedzenie v pracovnej pamäti. Túto interakciu vysvetl'uje nasledovnými spôsobmi: bud' si dyslektik oproti bežnému čitatel'ovi t'ažko vybavuje z pamäti fonetické predstavy, alebo problematické fonologické predstavy obmedzujú množstvo slov, ktoré si dyslektik dokáže udržat' v pamäti. Fonologické uvedomovanie je jazyková schopnost' jednotlivca, prostredníctvom ktorej chápe hláskovú štruktúru hovorenej reči, je schopný vyčleňovat' zvukové segmenty reči, t. j. slová, slabiky a hlásky a manipulovat' s nimi. Podl'a Matejceka (1995) ide o schopnost' identifikovat' zvuky, ktoré vytvárajú slová a asociovat' tieto zvuky s napísanými slovami. Deti v predškolskom veku ešte nevedia čítat', a teda ešte poväčšine nemajú vyvinuté fonologické uvedomovanie. Pre menšinu detí platí, že majú problémy vosvojovaní si tejto schopnosti, a preto t'ažko vnímajú reč v hlučnom prostredí, t’ažko sa vyjadrujú a problematicky realizujú krátkodobú pamät' v oblasti verbálnych informácií. „Fonematické uvedomovanie predpokladá, že si diet'a uvedomuje akustickú formu hovorenej reči a vie sa pritom abstrahovat' od obsahovej stránky slov a výpovede, vyčlení sluchom slová vo vetách, slabiky v slovách, a na najvyššej úrovni aj hlásky v slovách, ich poradie, počet atd'.“ (Lechta, 2002: 261). Autor vo vývine fonematického uvedomovania rozlišuje nasledovné štádiá: „ucho“ pre rýmy (už vo veku okolo troch rokov), uvedomovanie si segmentov reči, rýmov a aliterácií v slovách, delenie slov na slabiky (v predškolskom veku), zložitejšie manipulácie s fonémami v slovách vynechávanie, nahrádzanie a pod. (v školskom veku najmä pod vplyvom čítania a písania) (Lechta, 2002b).

Význam fonematického uvedomovania ako rozhodujúcej jazykovej schopnosti pri rozvíjaní čítania a písania bol výskumne potvrdený v rôznych jazykoch, ktoré využívajú hláskové písmo. Za najúčinnejšiu prevenciu porúch čítania teda väčšina vedcov považuje rozvíjanie fonematického uvedomovania predškolákov a rizikových skupín detí a žiakov (Mikulajova, 2014).

Mikulajova (2012) uvádza výsledky výskumov v anglosaskej rečovej oblasti (išlo o porovnávanie nemecky a anglicky hovoriacich dyslektických detí), kde sa ukázalo, že na pozadí vzniku dyslexie sú fonologické deficity: „Nácvik čítania ako taký automaticky rozvinie aj fonematické uvedomovanie, dôležité pre čítanie v každom jazyku. Čítaním sa teda podnecuje rozvoj fonematického uvedomovania a nie naopak. Bohatšia 
skúsenost' s čítaním potom nepriamo pozitívne ovplyvňuje aj schopnost' detí správne písat... Nemecky hovoriace dyslektické deti čítajú presnejšie a podstatne rýchlejšie v porovnaní $\mathrm{s}$ rovnakou vzorkou anglických dyslektikov. U oboch skupín detí sa však zistili deficity pri čítaní pseudoslov, i ked' rôzneho stupňa, čo je dôkazom fonologických deficitov na pozadí dyslexie v oboch jazykoch“ (Mikulajova, 2012: 54). Kvalita fonologických procesov sa zistuje prostredníctvom rôznych metód. V poslednom čase sa ako relevantné zdajú byt' najmä metódy, zistujúce schopnost' fonematického uvedomovania meraním schopnosti diet'at'a delit' slovo na slabiky, vyčleňovat' prvú hlásku v slovách a realizovat' syntézu slov z hlások. Pri zistovaní schopnosti diet'at'a delit' slovo na slabiky sa používa forma „vytlieskavania“ slabík. Vyčleňovanie prvej hlásky v slove sa skúma tak, že diet’at'u sú prezentované slová, pri ktorých má určit' akú hlásku počuje na ich začiatku, pričom je však vopred potrebné diet’at'u vysvetlit', čo sú hlásky. Pri zistovaní schopnosti hláskovej syntézy slov je diet'at'u prezentovaný rad izolovaných hlások, ktoré má za úlohu spojit' a vytvorit' tak slovo. Ide napríklad o tzv. hru na robota (Mikulajova a kol., 2012).

Rýchle automatické pomenovanie (Rapid Automatized Naming = RAN) je taktiež schopnost' považovaná za dobrý prediktor možných budúcich problémov v čítaní detí - jeho zistovaním sa dajú totiž poznat' faktory ako sú procesy percepcie, pozornosti, motoriky, pojmov. Ako uvádza Kucharská (2014) má táto úloha mnoho rôznych modifikácií: deti pomenovávajú podnetové situácie, usporiadané poväčšine $\mathrm{v}$ riadkoch alebo $\mathrm{v}$ tabul'ke. Podnetmi bývajú najčastejšie písmená, číslice, farby alebo obrázky známych predmetov. Pri skúške sa sleduje rýchlost' a chybovost' schopnosti rýchleho pomenovania. Princípom úlohy je vybavovanie fonologických predstáv z dlhodobej pamäti. Okrem krátkodobej fonologickej pamäti je RAN d’alším významným ukazovatel’om fonologických funkcií. Výskumy, ktoré podporujú hypotézu slabšieho výkonu v RAN v súvislosti s problémami v čítaní uvádzajú napr. Hulme a Snowlingova (2009: 59) alebo Kucharska (2014: 148). Mikulajova a kol. (2012) v tejto súvislosti upozorňujú na fínsky projekt longitudinálneho štúdia dyslektických detí (Jyvaskyla Longitudinal Study of Dyslexia), ktoré v piatich rokoch fyzického veku v RAN dosahovali signifikantne slabšiu úroveň oproti budúcim normálnym čitatel'om.

Problém tzv. pracovnej pamäti sa javí ako jeden z najzávažnejších faktorov predpovedajúcich neskoršie t’ažkosti $\mathrm{v}$ čítaní. Z hl’adiska retencie informácií v pamäti sa najčastejšie uvádza tzv. trojfázový model pamäti, ktorý predpokladá existenciu pracovnej (tiež operačnej, resp. senzorickej), krátkodobej a dlhodobej fázy. Pracovná pamät' slúži na podržanie informácie na rádovo sekundy (ide napr. o jednotlivé vlastnosti predmetov alebo javov teda napr. grafémy napísaného slova), kým nie je spracovaná pre použitie v nasledovnej fáze (krátkodobá pamät'). Mikulajova a kol. (2012) uvádzajú, že pracovná pamät' na jednej strane udržiava vnímané slová v pracovnej pohotovosti počas riešenia určitej úlohy, na druhej strane vyhl'adáva pre tieto slová významy uložené v dlhodobej pamäti. Kucharska (2014) uvádza, že pracovná pamät' zohráva spolu s fonologickými schopnostami dôležitú rolu pri takých náročných úlohách, ktoré majú predškolské deti zvládat', ako je napr. opakovanie slov alebo pseudoslov. Diet’a pritom počuje verbálne 
podnety, ktoré si musí zapamätat' a potom správne vyslovit'. Podl'a Smolika (2009) je tento typ úloh optimálnym diagnostickým markerom vývinovej dysfázie, pretože problémy spôsobuje práve deficit pracovnej pamäti pri podržaní materiálu fonologickej povahy.

Gramatický cit je schopnost' jednotlivca „zvládnut' pravidlá hovorenej reči bez ich teoretického osvojenia si tak, aby bol schopný na základe analógie a nápodoby, za spolupôsobenia faktorov biologických a spoločenských, hovorit' gramaticky správne“ (Zelinkova, 1994, p. 140). Význam gramatického citu pri čítaní spočíva $\mathrm{v}$ nutnosti predvídat' slová, ktoré budú nasledovat' $\mathrm{v}$ texte, $\mathrm{k}$ čomu je nevyhnutné poznat' gramatické pravidlá jazyka. Dyslektickí jednotlivci majú vo všeobecnosti problémy najmä s gramatickou (morfologicko-syntaktickou) a sémantickou stránkou vývinu jazykových schopností, a to v expresívnej aj impresívnej zložke reči, čo korešponduje s aktuálnou jazykovo-kognitívnou teóriou vzniku dyslexie, v rámci ktorej je zdôrazňovaná úloha jazykových deficitov, najmä t’ažkostí s osvojovaním si jazykovej formy (Mikulajova, 2009). Autorky Mikulajova a Rafajdusova (1993) upravili Skúšku jazykového citu Z. Žlaba, ktorá bola vytvorená na hodnotenie morfematického uvedomovania žiakov mladšieho školského veku. Pozostáva zo subtestov určovanie rodu podstatných mien (napr. lopta - tá), odvodzovanie slov pomocou derivačných morfém (napr. tvorba mužských a ženských názvov povolaní: lekár - lekárka), odvodzovanie prídavných mien z podstatných mien (napr. kniha pre deti detská), doplňovanie chýbajúcich slov do vety v správnom tvare (podstatné meno a zhoda podstatného mena s prídavným menom), utváranie minulého času slovies a určovanie koreňa slova vo viacerých odvodených slovách (lepidlo, lepit', nálepka, lepiaci - lep).

Okrem uvedenej metódy Mikulajova (2009) považuje za vhodné na meranie jazykového citu ešte napr. metódu Opakovania viet podla Grimmovej, TOKEN Test, a aj u nás známy a v našej praxi často využívaný Heidelbergský test rečového vývinu (HSET), ktorý považuje za vel'mi dobre zakotvený vo vývinovej psycholingvistickej teórii. Test má iba orientačné slovenské normy, napriek tomu ho autorka odporúča (pre vyššie uvedené výhody) využívat' vo výskume aj praxi. Test meria nasledovné úrovne jazykového procesu: Morfologickú štruktúru, vetnú štruktúru, slovný význam, vetný význam, interakčný význam a integráciu týchto úrovní a pozostáva $\mathrm{z}$ trinástich subtestov: Tvorba množného a jednotného čísla, Tvorba odvodených slov, Odvodzovanie prídavných mien, Porozumenie viet, Opakovanie viet, Klasifikácia pojmov, Hladanie slov, Oprava významovo nesprávnych viet, Tvorba viet, Spájanie verbálnych a neverbálnych informácií, Dekódovanie a kódovanie zámerov, Flexibilita pomenovania, Pamät' pre text

Narativne schopnosti považuje Mikulajova (2009) za vysoko citlivý indikátor všeobecného vývinu jazykových schopností. Podl’a autorky rozprávanie vyžaduje aktiváciu viacerých schopností, ako napríklad schopností fonologických (kvalita výslovnosti a zrozumitel’nost' reči), pamätových (vybavovanie slov z pamäti), morfologických (gramatická správnost'), syntaktických (tvorba viet), sémantických (slovná zásoba, vetný význam), pragmatických (schopnost' počúvat' a následná koherencia výpovede). 
Autorka vytvorila metódu na zistovanie a rozvoj naratívnych schopností detí, ktorá vedie k vytvoreniu správnej štruktúry naratívnej epizódy, ktorá má pozostávat' z úvodnej udalosti, vnútornej odpovede, plánu, pokusu, dôsledku, riešenia a záveru. „Kto dokáže zaujímavo rozprávat', je atraktívny spoločník v triede i mimo školy a deti sa rady pretekajú v rozprávaní zážitkov a príbehov. Súvis naratívnych schopností s čítaním je očividný: Porozumenie literárneho textu je dekódovaním takých príbehov a písanie je ich tvorbou“ (Mikulajova, 2009: 8).

Porozumenie reči je jazyková schopnost' vztahujúca sa ku kvalite porozumenia obsahu počutých viet. Kucharska (2014) uvádza, že túto jazykovú schopnost' je možné zist'ovat' vel'mi skoro (cca od štyroch rokov fyzického veku diet'ata). Autorka prezentuje skúsenosti s testom TROG (Test for Reception of Grammar) Dorothy. V. Bishopovej, ktorý ale zatial' v našich krajinách nie je štandardizovaný. Pôvodne bol test koncipovaný na meranie porozumenia reči dysfatických detí. Jeho podstatou je vol'ba jedného zo štyroch prezentovaných obrázkov, ktorý sa podl'a diet’at’a najviac zhoduje s počutým obsahom, pričom podnetové vety obsahujú tzv. distraktory nesprávny gramatický alebo lexikálny prvok, ktorý ich odlišuje od správnej odpovede. Autorka uvádza dobrú diferenciačnú schopnost' testu - celkový výkon detí so špecificky narušeným vývinom reči bol v štyroch vybraných subtestoch ovela slabší ako výkon intaktných detí. Porozumenie hovorenej reči významne podmieňuje procesy porozumenia pri čítaní, ako to definuje tzv. jednoduchý model čítania, ktorý definuje dva základné komponenty tvoriace proces čítania - dekódovanie a porozumenie. Dekódovanie je prekladom písaného slova do hovoreného. Porozumenie je chápanie významu slov, viet a textu. Ćítanie je potom súčinom dekódovania slov a ich porozumenia v hovorenej reči (Mikulajova a kol., 2012).

Poznanie pismen je podla niektorých výskumov silným faktorom predurčujúcim neskoršie úspešné zvládnutie čítania, pričom má úzky súvis s vývinom fonologického uvedomovania. Metaanalytická štúdia H. Scarboroughovej dokonca vypovedá o poznaní písmen ako o v poradí prvom prediktore predpovedajúcom budúcu kvalitu čitatel'ských schopností (Scarborough, podla Mikulajovej, 2008). V tejto súvoslosti Mikulajova a kol. (2014) píšu, že v predškolskom veku ide o propedeutiku čítania, pochopenie princípu, ako sa z písmen tvoria slová, nie o čítanie textu $\mathrm{v}$ pravom zmysle slova. Autorka uvádza, že „ciel'om grafémovej etapy (ide o druhú čast' Tréningu fonematického uvedomovania podl'a D. B. El'konina - pozn. autor) je, aby si deti prehíbili fonematické uvedomovanie aj v spojitosti so znalost'ou písmen (ide len o vel'ké tlačené písmená - pozn. autor) a pochopili „techniku“ čítania slov. Túto druhú čast' považujeme za fakultatívnu, ale vel'mi užitočnú zložku pregramotnostnej výchovy v materských školách“.

Meranie prediktorov porúch písanej reči slúži na včasnú diagnostiku detí, ktoré by mohli mat' $\mathrm{v}$ neskoršom veku problémy s čítaním, resp. dyslexiou. Okrem uvedených silných prediktorov, o ktorých sa aktuálne nazdávame, že s najvyššou pravdepodobnost'ou budú viest' $\mathrm{k}$ určeniu porúch písanej reči, existujú aj tzv. slabé prediktory, ktoré s poruchami čítania súvisia menej. Scarboroughová (In: Elbro, Scarborough, 2003) uvádza ich 
prehl'ad: vizuálna pamät', neverbálne IQ, motorické zručnosti, vizuálna diskriminácia, vizuálno-motorická koordinácia, socio-kultúrne prediktory.

\section{Tréning fonematického uvedomovania podl'a D. B. El'konina}

Riešenie problému na pojmovej úrovni sa javí byt' najviac efektívnym. K takémuto spôsobu riešenia problému však dieta musí postupne dospiet', nižšie vývinové štádiá však diet'at'u nedovol'ujú toto riešenie použit' $z$ dôvodu nedostatočnej zrelosti nervovej sústavy alebo nadpriemernej zložitosti riešeného problému. Na tomto mieste by sme preto chceli upozornit' na potrebu systematického a primeraného rozvíjania verbálnej komunikácie. Aktuálne máme u nás $\mathrm{k}$ dispozícii funkčný metalingvistický nástroj, ktorý verbálnu komunikáciu diet’at'a (najmä) predškolského veku adekvátne rozvíja. Ide o Tréning fonematického uvedomovania podl'a D. B. El'konina, ktorý systematicky rozvíja tzv. jazykové schopnosti a nepriamo tak umožňuje zlepšovat' kognitívny vývin diet'at’a. Jazykové schopnosti (gramatický cit, porozumenie reči, fonematické schopnosti atd'.) majú rozhodujúce postavenie voblasti rozvoja čítania. „Fonematické uvedomovanie má ešte osobitne dôležitú úlohu. Je to schopnost' vedome narábat' so segmentmi slov, uvedomovat' si zvukovú štruktúru slov, identifikovat' poradie zvukov reči v plynulom toku reči, uskutočňovat' hláskovú analýzu, syntézu a zložitejšie manipulácie so zvukmi reči (pridat', odobrat', menit' poradie hlások v slove)“ (Mikulajova, Dujcikova, 2001: 7). Autorka upozorňuje na diametrálnu odlišnost’ tradičnej analyticko-syntetickej metódy vyučovania čítania a El'koninovho prístupu. Predmetom tradičnej metódy je vzt’ah písmeno - hláska, pričom hláska je vyčleňovaná len na to, aby bola označená písmenom. Cítanie je potom inverzný postup. $Z$ vyslovovaného ret’azca grafém sa tvorí slovo. Jedným z faktov, ktoré však vzal El'konin do úvahy je, že fonémy si diet’a osvojuje skôr ako grafémy. Druhým faktom bolo, že jeho metódou sa deti neučia o celom okolitom svete, ale sú zamerané len na jednu čast' objektívnej reality - na jazykovú (metajazyk). Tretím faktom je, že diet'a sa neučí poznávat' hlásky v poradí na základe ich frekvencie v jazyku (ako je to v tradičnom prístupe), ale dichotómne, na podklade zist'ovania rozdielov, diferenciáciou: Rozlišujú samohlásky a spoluhlásky, tvrdé a mäkké slabiky, krátke a dlhé slabiky. Osvoja si pritom odborné pojmy (slabika, hláska, samohláska, spoluhláska), naučia sa, že fonémy majú rozlišovaciu (dištinktívnu) schopnost'. Základnou stratégiou učenia v podaní D. B. El'konina je systematický prístup, sprostredkovanie znalostí zo strany dospelého. Spontánnost', prirodzenost' učebnej činnosti diet'at'a, možnost' improvizácie, pokusu a omylu (ako napr. v prístupe J. Piageta) nevytvára optimálne podmienky na učenie. El'konin hovorí, že učenie ide krok za psychickým vývinom diet’at'a. Podl'a jeho názoru by však stratégie učenia mali, práve naopak, o krok predchádzat' spontánny vývin. Takýmto vedeckým prístupom sa dosiahne optimálna orientácia diet'at'a v probléme, ktorý má riešit', tu konkrétne v poznávaní hláskovej štruktúry slov. Ked’že väčšina detí v danom veku (predškolský) ešte nedokáže dobre identifikovat' ret’azec hlások len sluchovou cestou, používa El'konin vo svojej metodike grafické modelovanie. Napríklad jednotlivé fonémy sú graficky znázorňované farebnými žetónmi 
(červený, okrúhly žetón predstavuje samohlásku, žltý, štvorcový žetón spoluhlásku). Postupne dochádza $\mathrm{k}$ automatizácii jednotlivých úkonov diet'at'a, odpútaniu sa od grafickej podpory a riešenie problému začne prebiehat' iba v mysli diet'at'a. Mikulajova a Dujcikova (2001: 10) upozorňujú aj na d'alšie prednosti predkladanej metodiky: „Forma hry je pre diet'a daného veku najprijatel'nejšia. Vplyvom tejto metodiky dochádza tiež $\mathrm{k}$ rozvoju osobnosti diet'at'a, jeho pozornosti, kritického myslenia, sebakontroly. V neposlednom rade sa rozvíja aj zmysel diet'at'a pre kooperáciu, ked’že úlohy sú stavané na riešenie vo dvojiciach, alebo menších skupinkách." Tréning fonematického uvedomovania bol pôvodne adaptovaný na slovenské podmienky autorkami Mikulajovou a Dujcikovou (2001) a bol určený det'om od fyzického veku pät' rokov. Uplatňovat' sa mohol plošne ako vzdelávací program pre predškolákov, ale aj ako rozvíjací program pre deti s odloženou školskou dochádzkou, ako reedukačný program pre žiakov trpiacich poruchami učenia, a aj ako doplňujúci program pre žiakov, ktorých možno charakterizovat' ako slabších čitatel'ov. V januári 2015 bola metodika vydaná znova v prepracovanej verzii autorkami Mikulajovou, Tokárovou a Sumegiovou (2014). Teraz pozostáva z dvoch funkčných častí Predgrafémová etapa a Grafémová etapa.

\section{Výskumný súbor a organizácia výskumu}

Výskum úrovne prediktorov gramotnosti mal experimetnálny dizajn - bol zist'ovaný vplyv rozvíjacej metódy na úroveň fonematického sluchu detí v experimentálnej skupine v preteste a postteste, a tiež vzhl'adom na kontrolnú skupinu (taktiež v preteste a postteste). Výskum bol realizovaný v materskej škole v Nitre v priebehu školského roka 2016/2017. Materskú školu navštevovalo $\mathrm{v}$ danom školskom roku cca 160 detí a pozostáva $\mathrm{z}$ desiatich tried. Experimentálna skupina pozostávala z 21 detí. Z toho 18 detí bolo intaktných, jedno dievčatko malo diagnostikovaný Aspergerov syndróm, jeden chlapec mal diagnostikovaný vysoko funkčný autizmus a jeden chlapec mal potvrdené znížené mentálne schopnosti. Väčšina detí v experimentálnej skupine nastúpila do danej triedy v septembri 2014, d’alších 6 prichádzalo postupne počas nasledujúcich dvoch rokov. V triede boli vytvorené silné sociálne väzby a vo všeobecnosti vládla príjemná atmosféra, bez negatívnych javov (agresivita medzi det'mi, šikanovanie). Bežné metódy využívané $\mathrm{v}$ priebehu edukačného procesu boli v experimentálnej skupine doplnené o vybrané zložky z rozvíjacích programov, ako napr. Krok za krokom, M. Montessori, Nosnou metódou bol Tréning fonematického uvedomovania podl'a D. B. El'konina. Škola pozornosti. Deti boli zvyknuté na prácu v skupinách a rovnako aj na samostatnú prácu, čo sa následne pozitívne odrazilo aj počas realizácie tréningu fonematického uvedomovania. V triede bola využívala metóda problémového vyučovania a projektového vyučovania, na ktorom sa $\mathrm{z}$ časti podiel'ali aj samotní rodičia detí. Chorobnost' bola v priebehu školského roka 2016/2017 nízka, takmer celý rok bol prítomný plný počet detí v triede, čo umožnilo rovnomerné rozloženie tréningu fonematického uvedomovania. Experimentálnu skupinu tvorilo 8 dievčat a 13 chlapcov. V čase realizácie pretestu, bolo najmladšie diet'a vo fyzickom veku 4,9 roka (do školy nastúpilo ako 5,9 ročné, v rámci 
predčasného zaškolenia) a najstaršie malo 5,8 roka. Kontrolná skupina pozostávala $\mathrm{z}$ triedy, $\mathrm{v}$ ktorej bol počet detí rovnaký ako $\mathrm{v}$ skupine experimentálnej, t. j. 21 detí. Z celkového počtu bolo 20 detí intaktných, jednému diet'at'u bol diagnostikovaný Aspergerov syndróm a zároveň narušená komunikačná schopnost'. Deti začali danú materskú školu navštevovat' v septembri 2014, v septembri 2015 im boli pridelené nové učitel'ky. Klíma $\mathrm{v}$ triede bola mierne komplikovaná, komunikácia medzi det'mi viackrát zlyhala a konflikty neraz vyvrcholili $\mathrm{k}$ fyzickému napadnutiu. Spolupráca medzi det'mi bola hodnotená ako slabšia. Chorobnost' kontrolnej skupiny, v školskom roku 2016/2017 bola nízka, v mesiaci marec bol zaznamenaný jeden týždeň, počas ktorého absentovalo viac ako $50 \%$ detí v triede. Rečové schopnosti detí $\mathrm{v}$ kontrolnej skupine boli rozvíjané štandardným spôsobom, pomocou bežného programu pre materské školy. Kontrolnú skupinu tvorilo desat' dievčat a jedenást' chlapcov, najmladšie diet’a v skupine malo v čase realizácie pretestu 5,2 roka a najstaršie 6,5 roka. Experimentálnu aj kontrolnú skupinu charakterizoval rovnaký počet a podobné vekové zloženie detí.

Pretest v experimentálnej skupine bol realizovaný v septembri daného školského roku v priestoroch materskej školy, ktoré deti dobre poznali a testovanie tak prebehlo bez zbytočnej psychickej zát’aže z neznámeho prostredia. Rovnako bola det'om dobre známa učitel'ka, ktorá ich priebehom testu sprevádzala. Test prebiehal individuálnou formou a $\mathrm{z}$ okolia boli odstránené všetky možné rušivé podnety. V priebehu troch dní bolo otestovaných všetkých 42 detí, ktoré sa zúčastnili na experimente. Najväčšie t’ažkosti boli zaznamenané v siedmom subteste, zameranom na porozumenie reči. Deti mali problém zapamätat' si naraz dve inštrukcie (napr. „odober malý žltý kruh a polož ho vedl'a vel'kého modrého štvorca“) a správne riešenie sa snažili náhodne uhádnut'. Posttest bol v experimentálnej skupine realizovaný $\mathrm{v}$ júni daného školského roku. Doba realizácie intervencie predstavovala v tomto časovom období 10 mesiacov. Testovanie prebiehalo za rovnakých podmienok ako v septembri a zúčastnilo sa ho všetkých 21 detí. Bol pozorovaný subjektívne pozitívny pokrok detí v oblasti jemnej motoriky (správny úchop písacích pomôcok), cieleného zamerania pozornosti a trpezlivosti pri riešení jednotlivých úloh. V samotných subtestoch bolo zaznamenané výrazné zlepšenie $\mathrm{v}$ oblasti čítania písmen. Viaceré deti dokázali identifikovat' už všetky písmená a správne prečítat' predpísané slová. Kým niektoré čítali slabikovaním, iné čítali už plynule a v tomto období dosiahli elementárnu čitatel'skú úroveň (schopnost' čítat' krátke a jednoduché rozprávkové príbehy). Citel'né zlepšenie bolo pozorované aj v subteste zameranom na porozumenie reči. Deti boli lepšie sústredené a dokázali sa riadit' inštrukciami učitel'ky bez väčších problémov.

\section{Metódy}

$\mathrm{Na}$ meranie úrovne jazykových schopností detí v experimentálnej a kontrolnej skupine bol použitý Test prediktorov gramotnosti (Mikulajova a kol., 2012). Test pozostáva z ôsmych subtestov: Ćítanie písmen, Pamät' na čísla, Gramatický cit, Symboly, Fonematické uvedomovanie, Rýchle automatické pomenovanie (d’alej RAN), Porozumenie reči Orálna a Verbálna 
praxia. Na spracovanie získaných dát (porovnanie zmeny úrovne fonematického uvedomovania včase a medzi skupinami) bola použitá matematicko-štatistická metóda - Studentov T-test.

\section{Analýza a interpretácia výsledkov}

Získané hrubé skóre $\mathrm{v}$ Teste prediktorov gramotnosti bolo spracované štatistickým testom (T-test), pomocou ktorého boli porovnané výsledky v preteste a postteste oboch skupín v čase a rovnako aj výsledky v čase navzájom medzi oboma skupinami. V tabul'kách 1 až 4 uvádzame vždy početnost', aritmetický priemer, štandardnú odchýlku, testovacie kritérium T - testu a významnost' jednotlivých meraných prediktorov čítania a písanej reči, ktoré zároveň tvoria jednotlivé subtesty v Teste prediktorov gramotnosti Mikulajovej. Ide o Čítanie písmen, Pamät' na čísla, Gramatický cit, Symboly, Fonematické uvedomovanie, RAN (rýchle automatické menovanie), porozumenie reči a verbálnu a orálna praxiu. Predpokladali sme, že jednotlivé prediktory budú po intervenčnom zásahu v experimentálnej skupine vykazovat' vyššiu úroven̆, ako pred ním a vyššiu úroveň ako v kontrolnej skupine. Okrem subtestu Pamät' na čísla, pozorujeme v ostatných subtestoch $\mathrm{v}$ experimentálnej skupine $\mathrm{v}$ preteste nárast hrubého skóre (tabul'ka 1).

Tabulka 1: Porovnanie pretestového a posttestového výkonu detí v experimentálnej skupine

\begin{tabular}{|c|c|c|c|c|c|c|}
\hline \multirow{2}{*}{ subtest } & \multirow{2}{*}{$\mathbf{N}$} & \multicolumn{2}{|c|}{ AM } & \multirow{2}{*}{ SD } & \multirow{2}{*}{$\mathbf{t}$} & \multirow{2}{*}{$\mathbf{p}$} \\
\hline & & pretest & posttest & & & \\
\hline Čítanie písmen & & 6,7 & 17,7 & 6,73406 & $-7,4532$ & 0.000 \\
\hline Pamät' na čísla & & 4,8 & 6,6 & 4,11747 & 2,06692 & 0.052 \\
\hline Gramatický cit & & 8,5 & 13,2 & 2,93521 & $-7,4345$ & 0.000 \\
\hline Symboly & 21 & 20,2 & 38,9 & 9,59861 & $-8,9119$ & 0.000 \\
\hline $\begin{array}{l}\text { Fonematické } \\
\text { uvedomovanie }\end{array}$ & & 9,0 & 13,7 & 2,19848 & $-9,7273$ & 0.000 \\
\hline $\mathbf{R A N}$ & & 72,8 & 50,4 & 16,6087 & 6,17524 & 0.000 \\
\hline Porozumenie reči & & 4,8 & 9,0 & 2,3001 & $-8,4437$ & 0.000 \\
\hline Orálna a verbálna & & 8,2 & 13,3 & 2,49952 & $-9,2542$ & 0.000 \\
\hline
\end{tabular}


Legenda: RAN - rýchle menovanie, $N$ - početnost', $A M$ - aritmetický priemer, $S D$ - štandardná odchýlka, $t$ - testovacie kritérium, $p$ - významnost'

V kontrolnej skupine došlo taktiež k nárastu hrubého skóre v jednotlivých subtestoch, rovnako s výnimkou subtestu Pamät' na čísla (tabul'ka 2).

Tabul'ka 2: Porovnanie pretestového a posttestového výkonu detí $v$ kontrolnej skupine

\begin{tabular}{|c|c|c|c|c|c|c|}
\hline \multirow{2}{*}{ subtest } & \multirow{2}{*}{$\mathbf{N}$} & \multicolumn{2}{|c|}{$\mathbf{A M}$} & \multirow{2}{*}{ SD } & \multirow{2}{*}{$\mathbf{t}$} & \multirow{2}{*}{ p } \\
\hline & & pretest & posttest & & & \\
\hline Čítanie písmen & & 7,8 & 11,9 & 4,04852 & $-4,6355$ & 0.000 \\
\hline Pamät' na čísla & & 6,8 & 5,4 & 3,1141 & 2,03215 & 0.056 \\
\hline Gramatický cit & & 6,8 & 9,3 & 2,45919 & $-4,7474$ & 0.000 \\
\hline Symboly & & 20,4 & 27,5 & 5,96058 & $-5,4915$ & 0.000 \\
\hline $\begin{array}{l}\text { Fonematické } \\
\text { uvedomovanie }\end{array}$ & & 7,2 & 9,7 & 2,76801 & $-4,0994$ & 0.001 \\
\hline RAN & & 72,9 & 61,3 & 14,2919 & 3,71029 & 0.001 \\
\hline Porozumenie reči & & 3,9 & 5,3 & 1,63007 & $-4,0161$ & 0.001 \\
\hline $\begin{array}{l}\text { Orálna a } \\
\text { verbálna praxia }\end{array}$ & & 6,3 & 8,3 & 1,97484 & $-4,641$ & 0.000 \\
\hline
\end{tabular}

Legenda: RAN - rýchle menovanie, $N$ - početnost,'AM - aritmetický priemer, $S D$ - štandardná odchýlka, $t$ - testovacie kritérium, $p$ - významnost'

Pri hlbšej analýze priemerného skóre však môžeme konštatovat', že nárast hrubého skóre $\mathrm{v}$ experimentálnej skupine bol intenzívnejší ako v skupine kontrolnej (tabul'ka 4). V preteste sa skupiny navzájom odlišovali v hrubom skóre v dvoch subtestoch (Fonematické uvedomovanie, Orálna a verbálna praxia - paradoxne v prospech experimentálnej skupiny) (tabul'ka 
3), v postteste sa skupiny odlišovali vo všetkých subtestoch, okrem RAN, a to $\mathrm{v}$ prospech kontrolnej skupiny (tabul'ka 4).

V subteste Čítanie písmen, získali deti v experimentálnej skupine, na začiatku sledovaného obdobia, priemerné skóre 6,7 bodu a deti v kontrolnej skupine 8,7 bodu. Deti v kontrolnej skupine síce dosiahli v postteste priemerné skóre 11,9 bodu, teda môžeme povedat', že sa ku koncu školského roka ich výkon zvýšil, avšak experimentálna skupina dosiahla priemerné skóre až 17,7 bodu, čo je oproti kontrolnej výrazný rozdiel, ktorý považujeme za významný z hl'adiska úspešnosti realizovanej intervencie.

Tabul'ka 3: Porovnanie pretestového výkonu detí v experimentálnej a kontrolnej skupine

\begin{tabular}{|c|c|c|c|c|c|c|}
\hline \multirow{2}{*}{ subtest } & \multirow{2}{*}{$\mathbf{N}$} & \multicolumn{2}{|c|}{$\mathbf{A M}$} & \multirow{2}{*}{ SD } & \multirow{2}{*}{$\mathbf{t}$} & \multirow{2}{*}{$\mathbf{p}$} \\
\hline & & ES & $\mathbf{K S}$ & & & \\
\hline Čítanie písmen & & 6,7 & 7,8 & 10,4303 & $-0,4812$ & 0.636 \\
\hline Pamät' na čísla & & 4,8 & 6,8 & 4,82935 & 3,75042 & 0.156 \\
\hline Gramatický cit & & 8,5 & 6,8 & 5,33051 & 1,47375 & 0.156 \\
\hline Symboly & & 20,2 & 20,4 & 17,0957 & $-0,0511$ & 0.960 \\
\hline $\begin{array}{l}\text { Fonematické } \\
\text { uvedomovanie }\end{array}$ & & 9,0 & 7,2 & 3,32093 & 2,56269 & 0.019 \\
\hline $\mathbf{R A N}$ & & 72,8 & 72,9 & 54,0382 & $-0,0121$ & 0.990 \\
\hline Porozumenie reči & & 4,8 & 3,9 & 3,81601 & 0,97214 & 0.343 \\
\hline $\begin{array}{l}\text { Orálna a } \\
\text { verbálna praxia }\end{array}$ & & 8,2 & 6,3 & 4,28341 & 2,08874 & 0.050 \\
\hline
\end{tabular}

Legenda: ES - experimentálna skupina, KS - kontrolná skupina, RAN rýchle menovanie, $N$ - početnost', AM - aritmetický priemer, SD - štandardná odchýlka, $t$ - testovacie kritérium, $p$-významnost'

V subteste Pamät' na čísla, získali deti v experimentálnej skupine na začiatku sledovaného obdobia priemerné skóre 4,8 bodu a deti v kontrolnej skupine priemerne 6,8 bodu. V postteste dosiahli deti experimentálnej skupiny priemerné hrubé skóre 6,6 bodu a deti kontrolnej skupiny 5,4 bodu. Úroveň pamäti na čísla sa teda nezlepšila v experimentálnej, ani kontrolnej 
skupine, ale rozdiel tohto prediktora bol po ukončení intervencie vyšší $\mathrm{v}$ prospech experimentálnej skupiny.

V subteste Gramatický cit bolo pred intervenciou priemerné hrubé skóre detí experimentálnej skupiny 8,5 bodu a kontrolná skupina dosiahla priemerne 6,8 bodu. Výsledky oboch skupín sa na konci sledovaného obdobia od seba odlišujú. Priemerné hrubé skóre v experimentálnej skupine vzrástlo na 13, 2 bodu a v kontrolnej na 9,3 bodu, teda $\mathrm{k}$ zlepšeniu došlo v oboch skupinách, ale v experimentálnej skupine bol nárast markantnejší.

Tabul'ka 4: Porovnanie posttestového výkonu detí v experimentálnej a kontrolnej skupine

\begin{tabular}{|c|c|c|c|c|c|c|}
\hline \multirow{2}{*}{ subtest } & \multirow{2}{*}{$\mathbf{N}$} & \multicolumn{2}{|c|}{$\mathbf{A M}$} & \multirow{2}{*}{ SD } & \multirow{2}{*}{$\mathbf{t}$} & \multirow{2}{*}{$\mathbf{p}$} \\
\hline & & ES & KS & & & \\
\hline Čítanie písmen & \multirow{8}{*}{21} & 17,7 & 11,9 & 7,77113 & 3,39775 & 0.003 \\
\hline Pamät' na čísla & & 6,6 & 5,4 & 3,72204 & 9,67372 & 0.000 \\
\hline Gramatický cit & & 13,2 & 9,3 & 4,35398 & 4,13483 & 0.001 \\
\hline Symboly & & 38,9 & 27,5 & 18,1117 & 2,86753 & 0.010 \\
\hline $\begin{array}{l}\text { Fonematické } \\
\text { uvedomovanie }\end{array}$ & & 13,7 & 9,7 & 3,76133 & 4,93137 & 0.000 \\
\hline RAN & & 50,4 & 61,3 & 46,4903 & $-1,0796$ & 0.293 \\
\hline Porozumenie reči & & 9,0 & 5,3 & 3,23228 & 5,13092 & 0.000 \\
\hline $\begin{array}{l}\text { Orálna a } \\
\text { verbálna praxia }\end{array}$ & & 13,3 & 8,3 & 3,91152 & 5,85779 & 0.000 \\
\hline
\end{tabular}

Legenda: ES - experimentálna skupina, KS - kontrolná skupina, RAN rýchle menovanie, $N$ - početnost', AM - aritmetický priemer, $S D$ štandardná odchýlka, $t$ - testovacie kritérium, $p$ - významnost'

V subteste Symboly boli výsledky podobné. Zlepšenie nastalo v experimentálnej, aj kontrolnej skupine, ale $\mathrm{v}$ experimentálnej sme zaznamenali väčšiu diferenciu priemerného výkonu. $\mathrm{V}$ preteste dosiahla experimentálna skupina priemerné hrubé skóre 20, 2 bodu a kontrolná skupina 20, 4 bodu. Priemerné hrubé skóre na konci sledovaného obdobia 
predstavovalo $\mathrm{v}$ experimentálnej skupine 38, 9 bodu a v kontrolnej skupine 27,5 bodu.

V subteste Fonematické uvedomovanie, získali deti v experimentálnej skupine na začiatku sledovaného obdobia priemerné hrubé skóre 9 bodov a deti v kontrolnej skupine 7,2 bodu. V postteste predstavovalo priemerné hrubé skóre experimentálnej skupiny 13,7 bodu a kontrolnej skupiny 9,7 bodu. Skupiny sa teda odlišujú vzhl'adom na čas merania (v prospech posttestu), ako aj navzájom (v prospech experimentálnej skupiny).

V subteste Rýchle automatické pomenovanie (RAN), získala v preteste experimentálna skupina priemerne 72,8 bodu a kontrolná skupina priemerne 72,9 bodu. Na začiatku, aj na konci sledovaného obdobia, boli výkony oboch skupín vyrovnané. Na konci obdobia získala experimentálna skupina v priemere 50,4 bodu a kontrolná skupina 61,3 bodu. Schopnost' rýchleho automatického pomenovania teda paradoxne klesla počas sledovaného obdobia v oboch skupinách.

V subteste Porozumenie reči experimentálna skupina dosiahla pretestovú hodnotu priemerného hrubého skóre 4,7 bodu a v kontrolná 3,9 bodu. Experimentálna skupina dosiahla v postteste priemerné hrubé skóre 9 bodov a kontrolná 5,3 bodu. V oboch skupinách došlo teda k zlepšeniu schopnosti porozumenia reči, ale v experimentálnej skupine bolo zlepšenie intenzívnejšie.

V subteste Orálna a verbálna praxia, dosiahla experimentálna skupina $\mathrm{v}$ rámci pretestu priemerné hrubé skóre 8,2 bodu a kontrolná skupina 6,3 bodu. Experimentálna skupina dosiahla ku koncu sledovaného obdobia priemerné hrubé skóre 13,3 bodu a kontrolná skupina 8,3 bodu. Skupiny sa v schopnosti orálnej a verbálnej praxie odlišujú vzhl'adom na čas merania (v prospech posttestu), ako aj navzájom (v prospech experimentálnej skupiny).

\section{Diskusia a záver}

Už po prvých týždňoch realizácie programu bol pozorovatel'ný rozdiel medzi experimentálnou a kontrolnou skupinou. Reakcie detí experimentálnej skupiny boli sebavedomejšie, presnejšie, deti sa dokázali lepšie sústredit' a pochopit' inštrukcie dospelého. Významný nárast hrubého skóre bol zaznamenaný vo všetkých subtestoch (okrem subtestu Pamät' na čísla), ale najviac v subteste Č́tanie písmen, čo znamená, že deti v experimentálnej skupine po intervencii dokážu rozoznávat' písmená a čítat' jednoduché slová, bud' slabikovaním, alebo plynule lepšie, ako deti v kontrolnej skupine. Významný nárast bol pozorovaný aj pri úlohách vyžadujúcich dobré porozumenie hovorenej reči a cielené zameranie pozornosti. V subteste Pamät' na čísla nedošlo vplyvom intervencie v experimentálnej skupine k významnému zvýšeniu skóre, v kontrolnej skupine došlo dokonca $\mathrm{k}$ jeho poklesu. $\mathrm{V}$ rámci tejto schopnosti sa však deti experimentálnej a kontrolnej skupiny po intervencii odlišovali, a to v prospech detí experimentálnej skupiny.

Porovnanie výsledkov posttestu v experimentálnej a kontrolnej skupine potvrdil predpoklad, že jazykové schopnosti detí experimentálnej skupiny, vyjadrené hrubým skóre jednotlivých subtestov, budú po ukončení Tréningu fonematického uvedomovania podl'a D. B. El'konina vyššie, 
v porovnaní s kontrolnou skupinou. Výnimku tvorí RAN (Rýchle automatické pomenovanie), čo je možné odôvodnit' skutočnost'ou, že Tréning fonematického uvedomovania podl'a D. B. El'konina nie je priamo zameraný na zvyšovanie rýchlosti jednotlivých výkonov. Pozornost' je skôr orientovaná na schopnost' sústredit' sa, pohotovost' a rozvážnost', pričom autorka opakovane zdôrazňuje potrebu prihliadat' na vlastné tempo jednotlivých detí (Mikulajova, Dujcikova, 2001).

Zvýšenie úrovne jednotlivých jazykových schopností detí v kontrolnej skupine je možné pripísat' procesu zrenia, a tiež faktorom $\mathrm{v}$ podobe vhodných vonkajších podmienok.

Nedosiahnutie predpokladaného nárastu výkonu v niektorých subtestoch mohlo byt' taktiež spôsobené prítomnostou detí so špeciálnymi edukačnými potrebami v daných skupinách. Mikulajova a Dujcikova (2001) uvádzajú, že metodika nie je vhodná pre deti s poruchou autistického spektra, pre svoju vysokú mieru abstraktnosti, ktorú si nie sú schopné vysvetlit' a porozumiet' jej. Tieto zistenia boli potvrdené, avšak je potrebné rozlišovat' medzi rôznymi stupňami narušenia. Kým diet’a s Aspergerovým syndrómom nemalo väčší problém s uchopením problematiky, iné dieta s diagnózou vysoko funkčného autizmu, realizáciu daných úloh nezvládlo.

$\mathrm{Na}$ základe výsledkov výskumu odporúčame, aby bol Tréning fonematického uvedomovania podl'a D. B. El'konina zaradený Ministerstvom školstva, vedy, výskumu a športu SR do vzdelávacích osnov pre materské školy ako odporúčaný, metodický postup pre rozvíjaní jazykových zručností detí. Odporúčame, aby bol tréning realizovaný minimálne $1 \mathrm{x}$ týždenne a $\mathrm{v}$ ostatné dni boli jednotlivé segmenty danej metodiky podporované rôznymi hrami, rozvíjajúcimi rečové kompetencie detí. Odporúčame aby sa tréning realizoval na menšej skupine detí. Je možné to riešit' prítomnost'ou oboch triednych učiteliek na doobedňajších aktivitách, prípadne vytvorením tzv. medzi-zmien. Rozdelenie detí do dvoch menších skupín (cca po 12 členov) by tak zvýšilo efektivitu výchovno-vzdelávacieho procesu a to aj $\mathrm{v}$ iných aspektoch. Odporúčame vytvorit' účinnú spoluprácu medzi predškolskou triedou a prvým ročníkom základných škôl. Odporúčame realizovat' plošnú diagnostiku prediktorov problémov reči $\mathrm{v}$ materskej škole. Taktiež odporúčame realizovat' plošnú depistáž školskej spôsobilosti detí.

Z výsledkov nášho výskumu vyplynulo, že kvalitu jazykových schopností detí je možné výrazne ovplyvnit' už v materskej škole, čo môže následne viest' $\mathrm{k}$ zvýšeniu školskej úspešnosti detí. Tréning fonematického uvedomovania podl'a D. B. El'konina disponuje vysokou mierou schopnosti preventívneho pôsobenia v oblasti rozvoja jazykových schopností detí, a tým aj predchádzania vzniku, eliminácie, alebo zníženia rizika vzniku špecifických vývinových porúch učenia.

\section{Pod'akovanie:}

Táto práca bola podporovaná Agentúrou na podporu výskumu a vývoja na základe Zmluvy č. APVV-15-0368. 


\section{Bibliographic references}

DOJCANOVA MELISEKOVA, A. 2019. Influence of phonological awareness training on the level of language skills in the slovak language of a child with the hungarian mother tongue. In Slavonic Pedagogical Studies Journal, vol. 8, n. 2, doi:10.18355/PG.2019.8.2.4, ISSN 1339-8660

DUCHOVICOVA, J. a kol. 2019. Phonematic Awareness and Chosen Cognitive Functions of a Child. In European Journal of Contemporary Education, vol. 8, n. 4, DOI:10.13187/EJCED.2019.4.751.

DUCHOVICOVA, J. a kol. 2019. Level of auditory analysis, synthesis and active vocabulary and their intergender context. In XLinguae, vol. 12, n. 4, pp. 229-238, DOI: 10.18355/XL.2019.12.04.20.

ELBRO, C. - SCARBOROUGH, H. S. 2003. Early identification. In: P. Bryant \& T. Nunes (Eds.), Handbook of Children's Reading, pp. 339-359. Dordrecht: Kluwer Academic Publishers.

KUCHARSKA, A. 2014. Riziko dyslexie. Pregramotnostni schopnosti a dovednosti a rozvoj gramotnosti v rizikovych skupinach. Praha: Univerzita Karlova v Praze, ISBN 978-80-7290-784-7.

LECHTA, V. 2002. Terapia narusenej komunikacnej schopnosti. Martin: Osveta, ISBN 80-8063-092-5.

MACAJOVA, M. - GROFCIKOVA, S. - ZAJACOVA, Z., 2019. Creation of rhymes as part of the development of phonemic awareness of preschool children. In XLinguae, vol. 12, Issue 3, ISSN 1337-8384, DOI: 10.18355/XL.2019.12.03.06 .

MATEJCEK, Z. 1995. Dyslexie - Specificke poruchy cteni. Praha: H\&H, ISBN 80-85787-27-X.

MIKULAJOVA, M. 2008. Moznosti ranej predikcie vyvinovych poruch pisanej reci. Ceskoslovenska psychologie, LII, n. 1, pp. 59-69, ISSN 0009062X.

MIKULAJOVA, M. 2009. Jazykovo-kognitivne metody prevencie a terapie dyslexie. Bratislava: Mabag, s.r.o., ISBN 978-80-89113-74-3.

MIKULAJOVA, M. - DUJCIKOVA, O. 2001. Trening fonematickeho uvedomovania podla D. B. Elkonina. Bratislava: DIALOG, spol. s r. o., ISBN 80-968502-1-0.

MIKULAJOVA, M. - RAFAJDUSOVA, I. 1993. Vyvinova dysfazia specificky naruseny vyvin reci. Bratislava: Avicenum, ISBN 80-900445-0-6.

MIKULAJOVA, M. a kol. 2012. Citanie, pisanie a dyslexia s testami a normami. Bratislava: Slovenska asociacia logopedov, MABAG spol. s r. o., ISBN 978-80-89113-94-1.

MIKULAJOVA, M. - TOKAROVA, O. - SUMEGIOVA, Z. 2014. Trening fonematickeho uvedomovania podla D. B. Elkonina. Predgrafemova a grafemova etapa. Metodicka priruika. Bartislava: Dialog s r. o., ISBN 97880-968502-7-3.

SMOLIK, F. 2009. Vyvojova dysfazie a struktura ranych jazykovych schopnosti. Ceskoslovenska psychologie, LIII, n. 1, pp. 40-54, ISSN 0009062X.

SNOWLING, M. J. 2000. Dyslexia (second edition). Oxford: Blackwell Publishers.

ZELINKOVA, O. 1994. Poruchy uceni. Praha: Portal, ISBN 80-7178-481-8. 
PhDr. Viktor Gatial, PhD.

Department of Pedagogical and School Psychology

Constantine The Philosopher University in Nitra

Drazovska 4

94901 Nitra

Slovak Republic

vgatial@ukf.sk 